\title{
Anatomy of salt excretory structures in certain halophytes in Egypt with a special reference to their re- naming and classification
}

\author{
Abd El-Salam Al- Nowaihi \\ E- mail: abdelsalamalnowaihi @ hotmail.com
}

and

\author{
Magdy M. Mourad \\ Department of Botany, Faculty of Science, Ain Shams University, \\ Cairo, Egypt.
}

Al-Nowaihi A.S. \& Mourad M.M. 2001. Anatomy of salt excretory structures in certain halophytes in Egypt with a special reference to their re-naming and classification Taeckholmia 21(1):45-58.

\begin{abstract}
The anatomy of salt excretory structures was studied in 22 dicotyledonous and monocotyledonous halophytic species; 13 of which were not previously investigated. The material was selected to represent obligate and facultative, and succulent and non- succulent halophytes. Structural variations led to their re- naming and classification. For more precise naming it was believed that one should differentiate between 'glands' that have no ontogenic relation to the epidermis and the epidermal appendages, and convinced by this, the excretory structures were classified into three types and two sub-types. It was also concluded that the presence of such structures in facultative halophytes, where the concerned stress factor (salinity) is absent, makes it a hereditary character resulting in an adaptive capacity for salt tolerance. Ectodesmata were recorded in the outer periclinal walls of the epidermal cells in some species and were considered to be another mechanism for salt excretion.
\end{abstract}

Key words: Anatomy, ectodesmata, excretory structures, halophytes, salt glands.

\section{Introduction:}

It has long been settled that halophytes have developed various strategies to tolerate the high salinity in their growth media. These strategies are either phenological examplified by the work of Waisel (1961), Pollak \& Waisel (1970), Monney et al. (1974), Liphschitz \& Waisel (1974), Taleisnik \& Anton (1988), Rajput \& Sen (1991), Freitag \& Breckle (1992) and Das (1999); Physiological and / or biochemical examplified by the work of Arisz et al. (1955), Helder (1956), Lüttge (1971), Campbell et al. (1974), Drennan et al. (1985), Hagemeyer \& Waisel (1988), Waisel (1991), Dschida et al. (1992), Drennan et al. (1992) and Salama et al. (1999); or structural by developing salt glands examplified by the work of Ziegler \& Lüttge (1966 \& 1967), Thomson \& Liu (1967), Shimony \& Fahn (1968), Levering \& Thomson (1971), Pollak (1973), Hill \& Hill (1973), Liphschitz et al (1974), Sakai (1974), Campbell \& Thomson (1976), Fahn \& Shimony (1977), Drennan et al. (1985 \& 1987), Weiglin \& Winter (1991), Bosabalidis (1992), Dschida et al. (1992), Balsamo \& Thomson (1993) and Salama et al. (1999).

In the Egyptian flora, the halophytes amount to 80 species; 30 of which are salt excretives (Batanouny \& Abo Sitta, 1977). Zahran (1982) classified 38 halophytic communities into 11 succulent, 13 excretive and 14 comulative. 
In Egypt and except for Aeluropus lagopoides investigated by Salama et al. (1999), no other work has been done on monocotyledonous species. As regards the dicotyledons the same authors (Salama et al., 1999) investigated the anatomical structure of the salt glands in 11 halophytic species and categorized them into four groups.

In the present work we are testing the presence and investigating the structural variations of the salt excretory structures in 17 dicotyledonous and five mnocotyledonous species for precise naming and classification.

\section{Material and Methods}

Fresh leaves of 19 species and herbarium specimens of three species were investigated. The species were selected to represent obligate and facultative, and succulent and non- succulent halophytes (Table 1). Some of the selected species have long been described as salt tolerants. So for as the available literature is consulted, nine of the 17 dicot species and four of the five monocots were not previously investigated.

The fresh material was collected from salt marshes in both the North coast of the Mediterranean and the Red Sea regions. The material of the facultative halophytes was collected from both saline and non- saline habitats. One species, Plumbago capensis is horticultural and cultivated under mesophytic conditions.

For microscopic investigation, the leaves were fixed and pickled in FAA. For dried herbarium specimens, the leaves were first softened and cleared by boiling in $10 \%$ $\mathrm{NaOH}$. Customary methods of dehydration, infiltration and embedding were followed (Johansen, 1940), sections were cut at 8-12 $\mu \mathrm{m}$, then stained in safranin-fast green combination and mounted in Canada Balsam. LM photographs were taken on Kodak TMAX 100 film.

\section{Observations and Discussion}

Avicennia marina ( $1_{\mathrm{a} \& \mathrm{~b}} \& 2_{\mathrm{a} \& \mathrm{~b})}$ - The excretory structures occur on both the adaxial and abaxial faces of the leaf. Those on the adaxial face are sunken in crypts; while those on the abxial face are raised above the epidermal cells. In either case the excretory structure is formed of 4-8 excretory cells enclosed within a cuticular chamber created by the curvature of the cuticle. The excretory cells are supported by two small disc- like stalk cells, and the latter are supported in turn by one median and two lateral collecting cells. Both the excretory and the stalk cells contain dense cytoplasm and numerous minute vacoules. Unlike the adaxial structures, the abaxial ones are bordered by non- glandular hairs consisting of 2-4 cells and the upper- most one becomes inflated to assume a bladder shape.

These observations on the excretory structure in Avicennia marina agree with those reported by Fahn \& Shimony (1997), Drennan et al (1987) and Carpenter et al (1990), all investigating the same species. However, Fhan \& Shimony (op. cit.) overlooked the presence of the bladder hairs, recorded in the present work, that border the abaxial glands.

A similar structure with one stalk cell was also observed in some other Avicennia species namely A. nitida (Chapman, 1944) and A. germinans (Dschida et al, 1992 and Blasmo \& Thomson, 1993). Dschida et al (op. cit.) believed that the multiseriate 
epidermis in A. germinans could provide a potentially large storage reservoir for salt delivered from the xylem. In A. marina, the abaxial epidermis is uniseriate but carries the bladder hairs. It could be presumed that such hairs in A. marina may perform the function of the multiseriate epidermis in A. germinans; thus acting as a reservoir that provides salt during the intermittent period of low salt status. However, this presumption should be substantiated by chemical criteria.

Meanwhile, we adopt the proposal of Salama et al. (1999) that both the crypts and the hairs increase the relative humidity around the glands; thus increasing the efficiency of salt excretion.

Frankenia revoluta ( $3_{\mathrm{a} \& \mathrm{~b}}$ ) and Tamarix nilotica (4a\&b)- Similar sunken excretory structures are present on both leaf surfaces. Each is composed of six cells in two parallel rows; each of three. The excretory cells have dense cytoplasm and supported by two large vacuolated collecting cells; one for each row. A cuticular layer encloses the excretory cells except at two transfusion areas between the collecting cells and the lower- most excretory cell in each row. The cuticular chamber above all the excretory cells is partitioned into two chambers through the inward growth of the inner face of the cuticle.

This type of excretory structure is similar to that investigated by Campbell \& Strong (1964) in Tamarix pentandra; by Thomson \& Liu (1967) in T. aphylla; by Campbell \& Thomson (1976) and Blasmo \& Thomson (1993) in Frankenia grandifolia, F. revoluta, Tamarix aphylla, T. nilotica, T. passerinoides and T. amplexicaulis by Salama et al. (1999). All the above workers termed it a 'gland'.

Reaumuria hirtella ( $5_{\mathrm{a} \& \mathrm{~b}}$ )- This species was not investigated before. Sunken excretory structures are present on both leaf surfaces. Each is formed of three superposed excretory cells supported by large vacuolated collecting cells. The excretory cells have dense cytoplasm, large nucleus and enclosed by a cuticular layer. A similar structure was also observed in Tamarix passerinoides by Salama et al. (1999) and termed it a 'gland'.

Limoniastum monopetalum ( $6_{\mathrm{a} \& \mathrm{~b}}$ ) and Limonium pruinosum ( $7_{\mathrm{a} \& \mathrm{~b}}$ )- In both species sunken excretory structures are present in both surfaces. Each consists of 8-16 more or less fusiform cells; the innermost of which are excretory and surrounded by accessory cells. The latter in turn are surrounded by cup- shaped collecting cells. These observations agree with those of Faraday \& Thomson (1986a) in Limonium species, Vassilyev \& Stepanova(1990) in Limonium platypyllum and Salama et al (1999) in Limoniastrum monopetalum, Limonium axillare and L. pruinosum.

Plumbago capensis $\left(8_{\mathrm{a} \& \mathrm{~b}}\right)$-The excretory structure is abaxially situated and leveled with the epidermal cells. It consists of four inner central excretory cells, surrounded by outer four accessory cells and an outer most ring of four collecting cells.

The same structure was observed in the same species by Sakai (1974) and Stepanová (1983). 


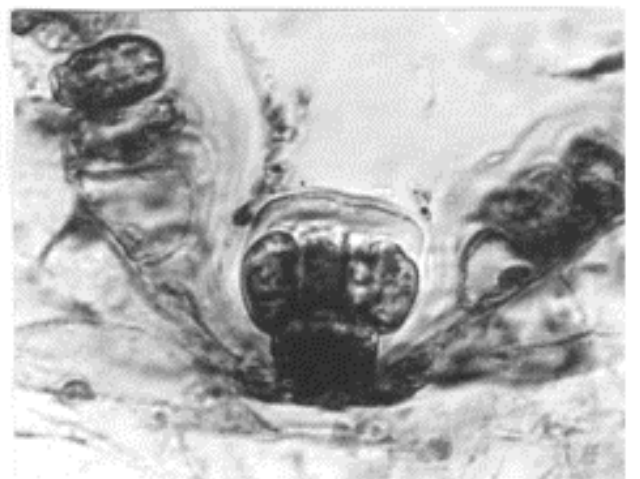

$1 \mathrm{a}$

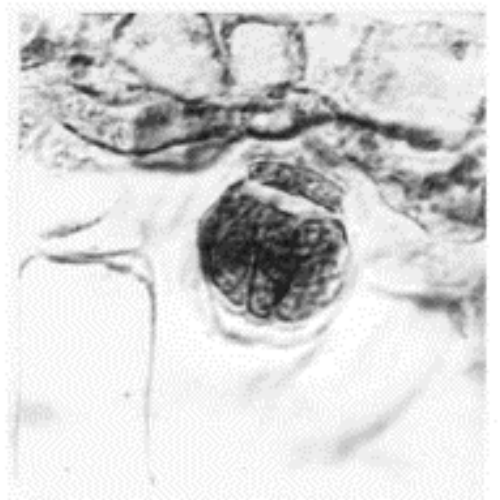

2 a

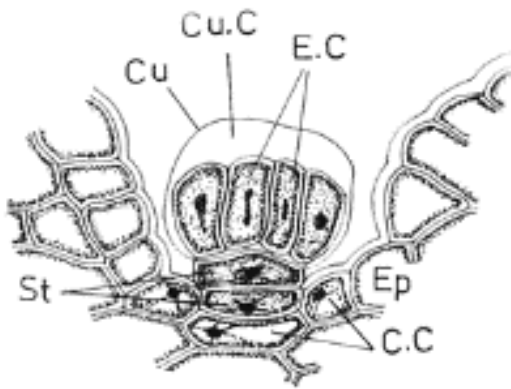

1 b

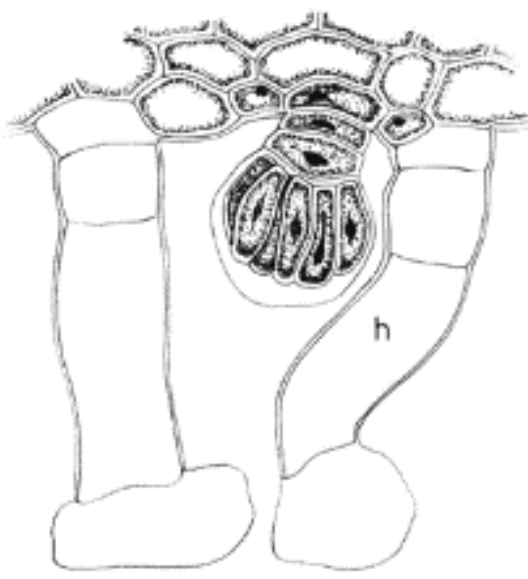

2 b

Photomicrographs (a) and Figures (b) of the excretory structures in the studies taxa. Adaxial gland (1a \& b) and abaxial gland (2a\&b) in Avicennia marina. C. C, Collecting cells; Cu, Cuticle; Cu. C, Cuticular chamber; E.C, Excretory cells; Ep, Epidermis; h, Hairs; St, Stalk cells. (X 500). 


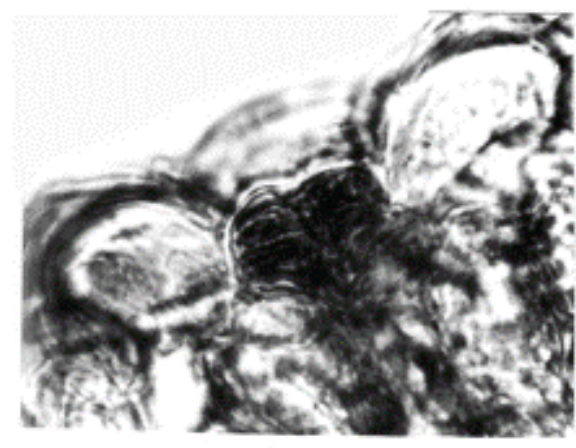

3a
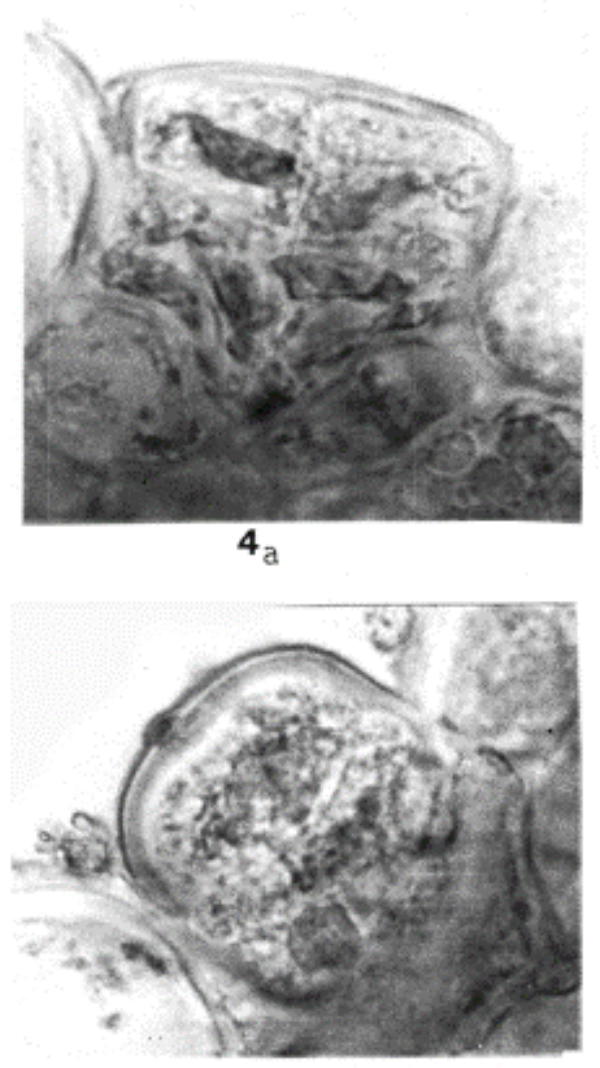

5 a
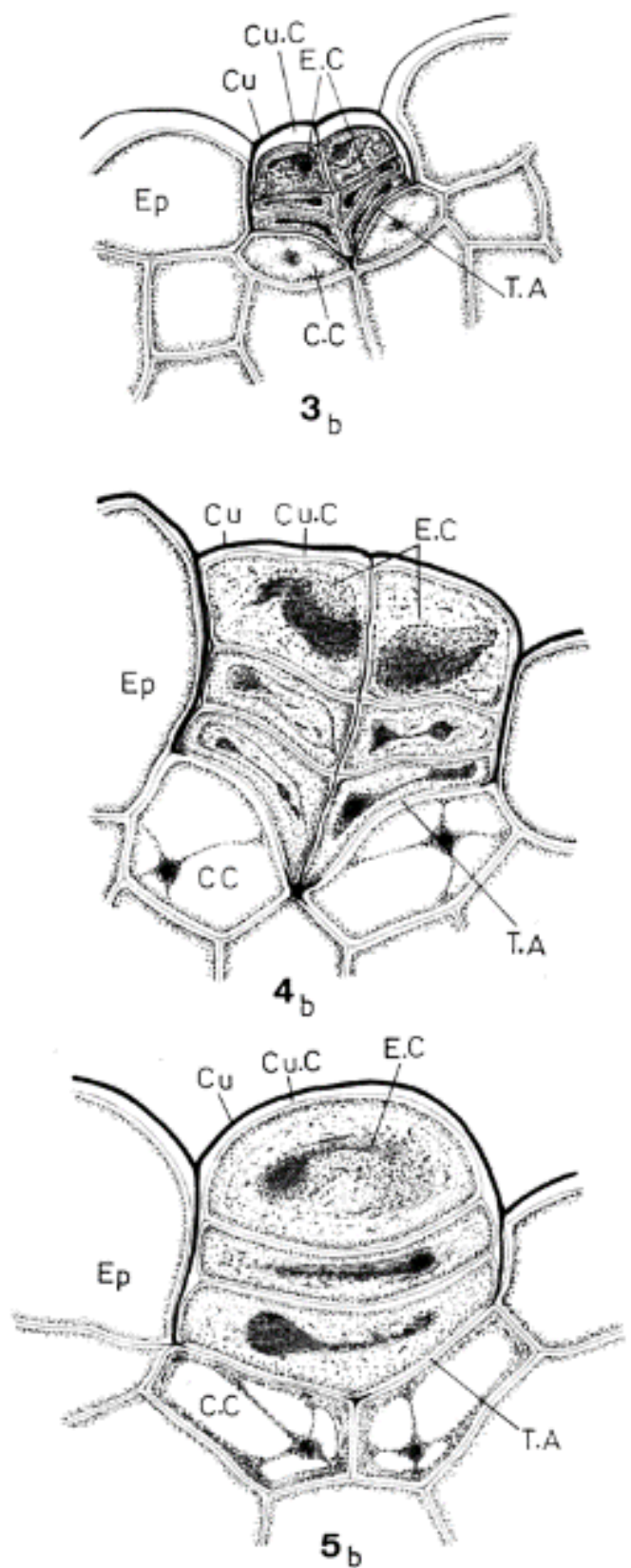

Photomicrographs (a) and figures (b) of Frankenia revoluta (3a \& b), Tamarix nilotica (4a \&b) and Reaumuria hirtella (5a \& b). Cu, Cuticle; Cu.C, Cuticular chamber; E.C, Excretory cells; Ep, Epidermis; T.A, Transfusion area. (X 500). 


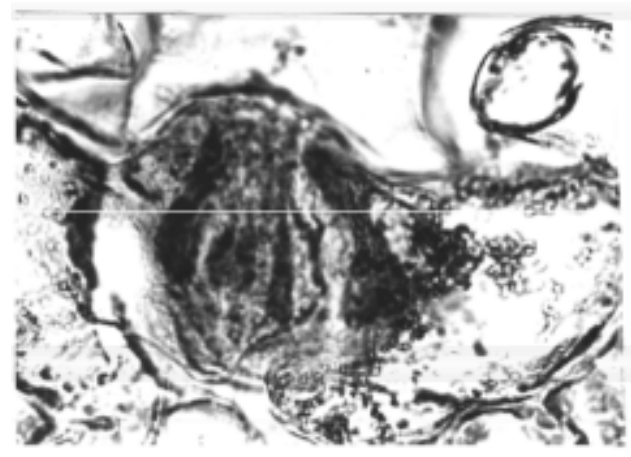

$6_{a}$
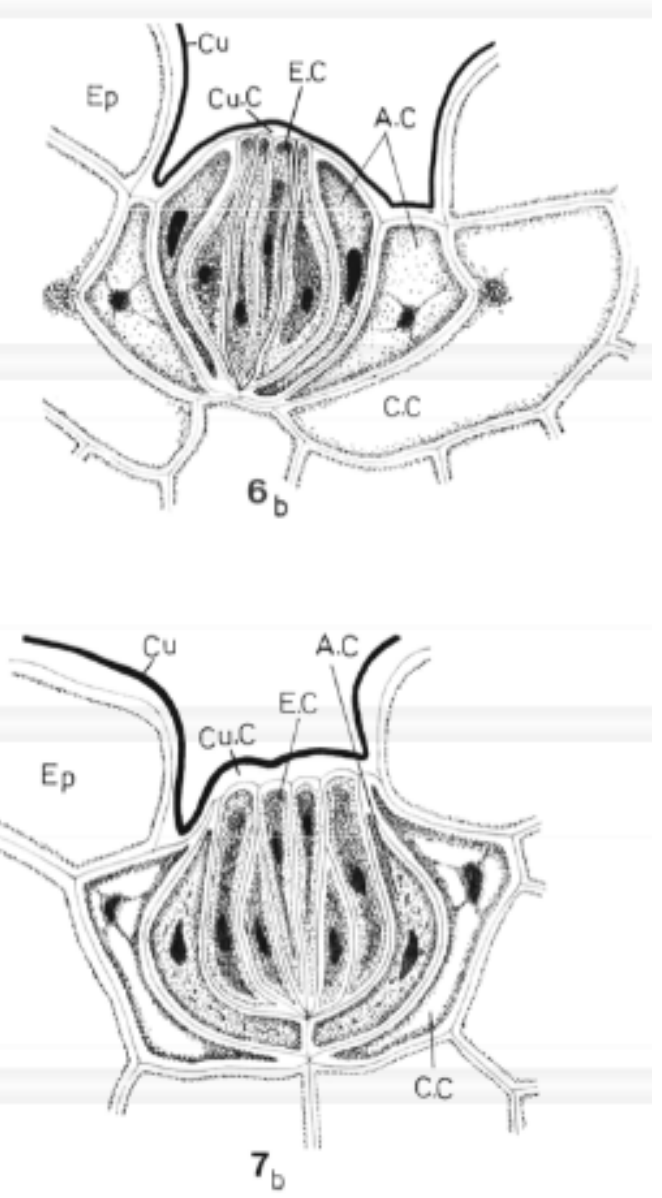

$8_{b}$

Photomicrographs (a) and figures (b) of Limoniastrum monopetalum (6 a \& b), Limonium pruinosum (7 a \& b) and Plumbago capensis (8a \&b). A.C, Accessory cell; C.C, collecting; cells Cu, Cuticle; Cu.C, Cuticular chamber; E.C, Excretory cell; Ep, Epidermis. (X 500). 
Atriplex halimus ( $\left.9_{\mathrm{a}} \& \mathrm{~b}\right)$, Chenopodium album and Beta vulgaris $\left(10_{\mathrm{a}} \& \mathrm{~b}\right)-$ The latter species was not investigated before. Except for Atriplex halimus with trichomes on both surfaces, the other two species carry similar trichomes which are confined to the abaxial surface. In all these facultative species, the trichome consists of a bladder cell overtopping one- three stalk- cells. The number of the stalk cells and the size of the bladder vary with the age of the trichome. Density of these trichomes is correlated with the habitat; being more dense in case of increased salinity.

Lüttge (1971) and Waisel (1972) described these trichomes as vesiculated and stated that the bladder hairs are a mechanism for salt deposition on the leaf surface; where the bladder hair becomes filled with salt water until it ruptures releasing the salt on the leaf. Similar structure of trichomes was observed in some Chenopodium species by Reiman \& Breckle (1988), in Atriplex triangularis by Karimi \& Unger (1989), in Atriplex species by Rajput \& Sen (1991), in ten Chenopodium species by Deng et al. (1998) and in Atriplex halimus and A. farinosa by Salama et al. (1999).

Aeluropus lagopoides (11 $1_{\mathrm{a}}$ b) and Chloris virgata (12 a \&b)-The latter species was not investigated before. The salt excretory structure consists of two cells; a basal one and an upper cap cell.

Pollak and Waisel (1970) observed a similar structure in Aeluropus littoralis and described the basal cell as collecting and the upper one as excretory. In the present work the same description is adopted to Aeluropus Lagopoides and Chloris virgata. Moreover, this basic structure was recorded in many halophytic species of the Gramineae; particularly in Spartina foliosa (Levering \& Thomson, 1971), in Chloris gayana (Liphschitz et al, 1974) and in two species of Pappophorum (Taleisnik \& Anton, 1988).

Discussing this phylogenetically through the study of 25 glycophytes belonging to the same family Liphschitz \& Waisel (1974) concluded that, the possessing of the salt glands in the concerned species suggests that they arose from a common halophytic ancestor.

Carex extensa, Cyperus capitatus and C. Iaevigatus (13a \& b). The three species were not previously investigated. The excretory structures in these species are the same as those in the Gramineae except for the tapering apex of the cap cell. In Cyperaceae similar epidermal structures termed papillae have long been observed in a number of species (Metcalfe, 1971). Mourad (1984) recorded the same type of papillae in 18 species from Cyperaceae growing in Egypt.

Earlier to this, Helder (1956) used the term "salt glands" for these papillae. Describing these papillae as being "salt glands" was also accepted by Levering \& Thomson (1971), Pollak \& Waisel (1971), and Liphschitz et al (1974). Like the suggestion of Liphschitz \& Waisel (1974) for Gramineae, It is also suggested that facultative members of Cyperaceae may have evolved from closely related or even from saline ancestors. 

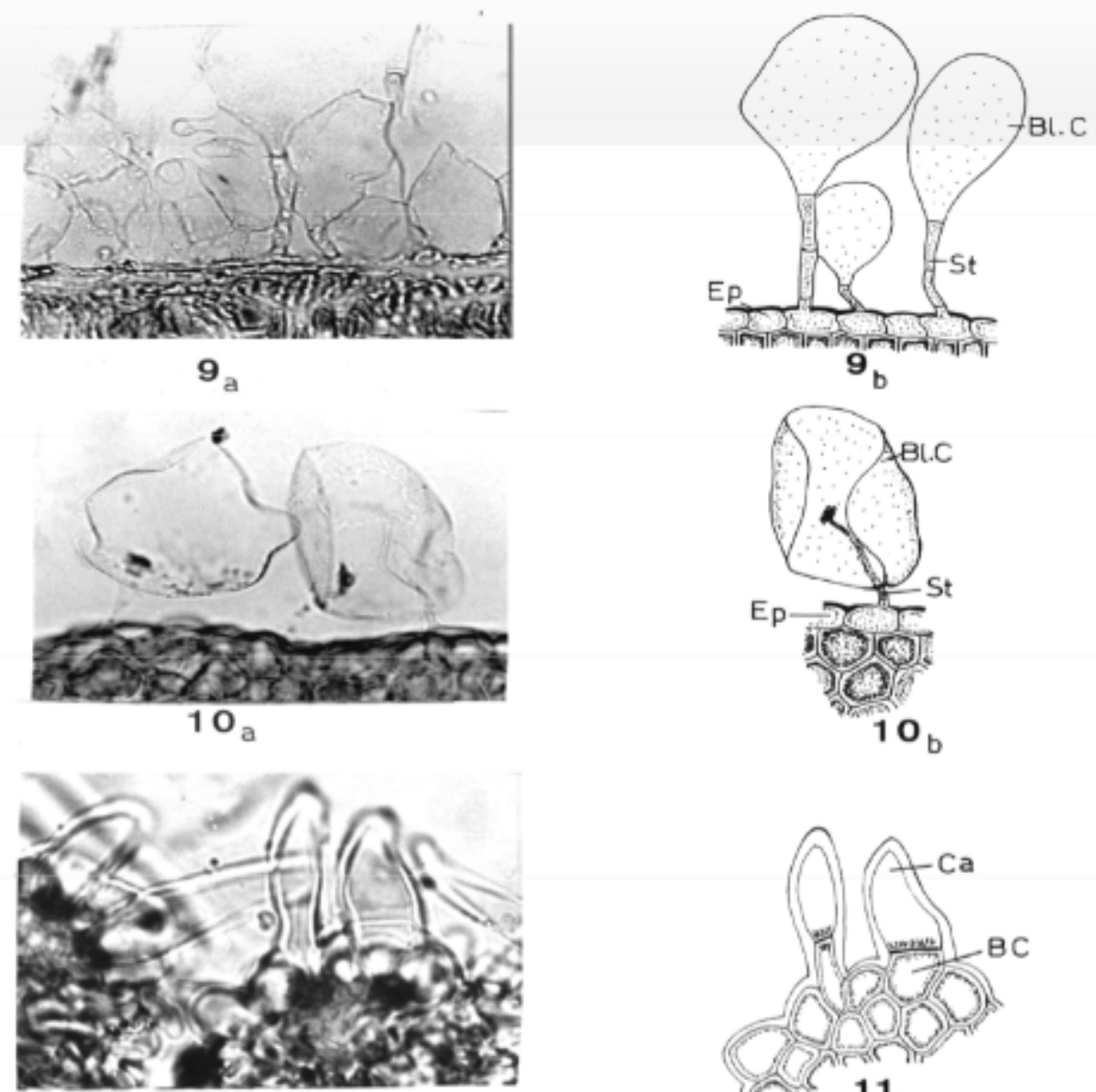

$11_{\text {a }}$
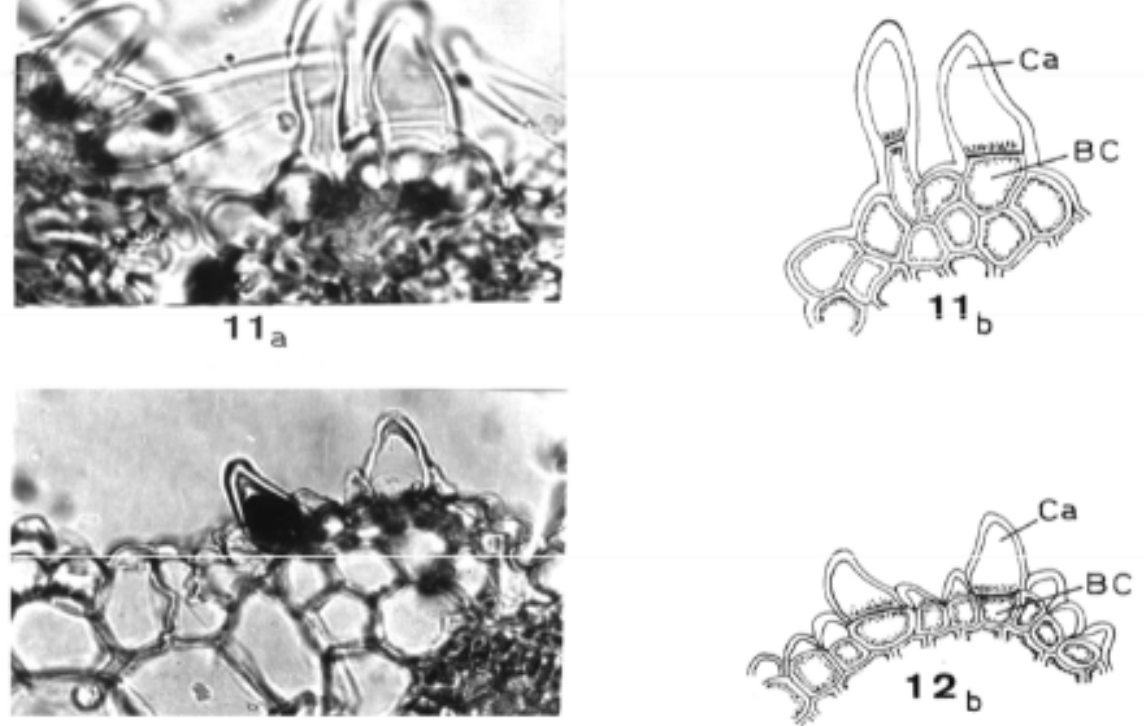

12 a

Photomicrographs (a) and Figures (b) of Atriplex halimus (9 a \& b), Beta vulgaris and Chenopoduim album (10a \& b). Aeluropus lagopoides (11a \& b) and Chloris virgata( 12 a \& b). B.C., Basal cell; Bl.C, Bladder cell; Ca, Cap cell; Ep, Epidermis; St, Stalk cells (X 500). 


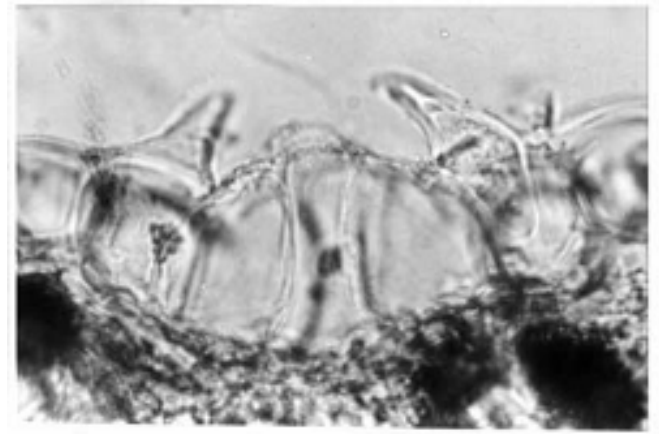

$13 \mathrm{a}$

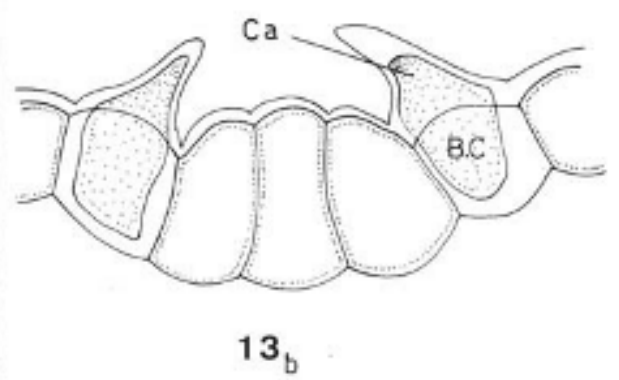

13

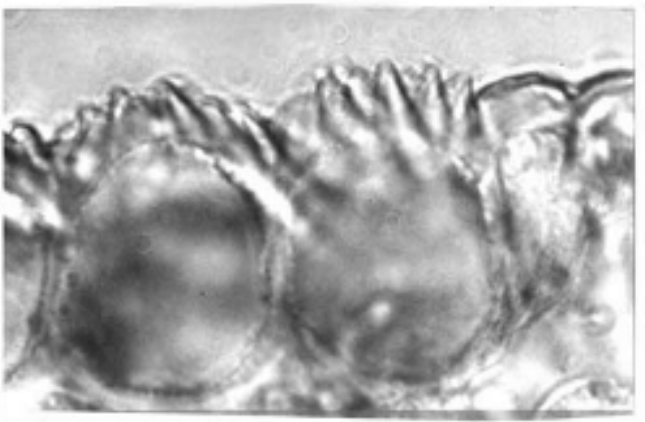

$14 \mathrm{a}$

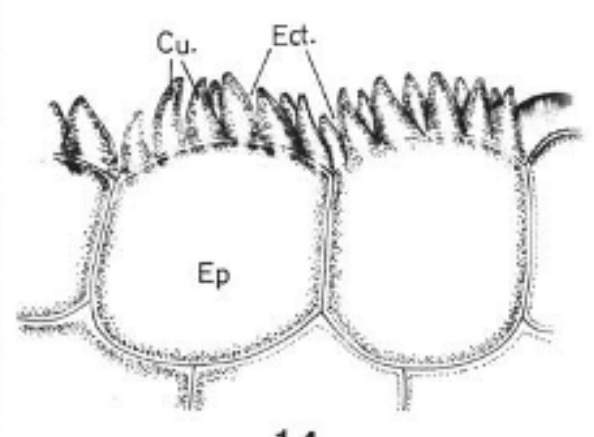

$14_{b}$

Photomicrographs (a) and Figures (b) of Carex extensa, Cyperus capitatus \& C. laevigatus (13 a \& b) (X 500) Crucianella maritima \& Spergularia marina (14 a \& b). (X 1000) B.C., Basal cell; Ca., Cap cell; Cu , cuticle (Wedge- haped); Ect., Ectodesmata; Ep, Epidermis

Crucianella maritima and Spergularia marina (14a\&b). Both species were not investigated before and the present investigation shows the lack of excretory structures. At the same time ectodesmata were observed in the outer periclinal walls of some epidermal cells.

It has long been known that the plasmodesmata are located in the anticlinal cell walls and adjoining the protoplasts. The periclinal cell walls of the epidermis may as well have plasmodesmata but opening to the outside; and where these were recorded they were termed 'ectodesmata'. Lambertz (1954), Schumacher \& Lambertz (1956), Schumacher (1957), Schnepf (1959) and Sievers(1959\& 1960) recorded the presence of ectodesmata in a number of plants. 
In Crucianella maritima and Spergularia marina the salt released through the ectodesmata become accumulated under the cuticle, thus exerting a pressure which causes the rupture of the latter and its fragmentation into wedge- shaped portions. Franke (1961) stated that the ectodesmata are thought to be the pathways for substances that are discharged to the outside. Likewise, the ectodesmata in our investigated species can be considered as a pathway for salt excretion. Where ectodesmata are also lacking, salt discharge occurs through cuticular pores. Juniper \& Jaffree (1983) claimed that the cuticle above the salt gland is perforated.

Cakile maritima, Inula crithmoides, Salicornia europaea, Suaeda pruinosa and Zypophyllum album- All these species were not investigated before. In these succulent species, neither excretory structures nor ectodesmata were recorded. Needless to say, that a general concept is that succulence is one mechanism for salt tolerance.

From the bulk of observations and discussion that have been presented, marked structural variations are recorded in the investigated species having salt excretory structures. Carlquist (1959) claimed that there is no sharp division between glandular hairs and glands, and the simple trichomes derived entirely from the epidermis integrade with emergencies. He also added that, the more complex structure may be called glands. In almost all the literature reviewed, the term "salt gland" was applied not only to particular cells described as secretives or excretives together with associated cells, but also to the vesicled hairs in Atriplex species and other halophytic chenopods and to the papillate epidermal cells of the halophytic members of the Gramineae and the Cyperaceae. In the latter two families the present authors suggest that the term "papillae" is better conserved for non- halophytic members since they are functionless. Where the papillae are functional in obligate halophytic members they are better termed glands. Irrespective to the ontogeny or the developmental anatomy of these structures and leaning on Carlquist claim (op.cit) about the overlapping of the terminology applied, the present authors do not favour the generalization of the term "salt gland". It is believed that one should differentiate between structures formed of cells that have no ontogenic relation to the epidermis on one hand and the epidermal appendages of any kind on the other hand.

For practical purpose this segregation leads to different naming and classification of the excretory organs s.lat. and for this, the subsequent types are suggested:

Type I. Gland complex- The complex is formed of more than two excretory cells with dense cytoplasm, enclosed in a cuticular chamber and with or without a stalk.

This type is subdivided into two subtypes:

Subtype 1 - The gland complex is stalked. (Avicennia marina).

Subtype 2- The gland complex lacks the stalk (Tamarix nilotica.

Frankenia revoluta,Reaumuria hirtella, Limoniastrum monopetalum,

Limoinum pruinosum and Plumbago capensis).

Type II. Bicellular gland which consists of one collecting cell and one secretory cell. (Aeluropus lagopoides, Chloris virgata, Carex extensa, Cyperus capitatus and C.laevigatus).

Type III: Vesiculated hairs (Atriplex halimus, Beta vulgaris and Chenopodium album). 
There remains another mechanism for salt excretion through the ectodesmata. These are neither entire cells nor epidermal appendages. They are cytoplasmic strands leading to the outside and responsible for the salt discharge.

\section{Concluding Remarks}

1. The type of the excretory structure is consistent at the family level (e.g. Chenopodiaceae, Verbenaceae, Plumbaginaceae), and sometimes in closely related families (Tamaricaceae \& Frankeniaceae and Gramineae \& Cyperaceae).

2. For Gramineae and Cyperaceae the term "papillae" was traditionally applied to the excretory structures. Only for non- halophytic members of both families the retention of the term is accepted since the papillae are functionless. But in the halophytic members it is preferable to adopt the term "glands" since they become functional.

3. The presence of a salt excretory mechanism in facultative halophytes as well,although the stress factor (salinity) is eliminated, would refer to the hereditary nature of this character resulting in an adaptive capacity for salt tolerance

4. Although the ectodesmata in the outer periclinal walls of the epidermal cells have been described as pathways for the discharge to the outside, there was no clear reference to salt discharge through them. Ectodesmata are neither glands nor appendages. They are cytoplasmic strands through which salt is discharged to the outside and thus considered to be an additional mechanism for salt excretion.

\section{References}

Arisz W.H., I.J. Camphuis, H. Heikens \& A.J. Van Tooren. 1995. The secretion of the salt gland of Limonium Latifolium Ktze. Acta. Bot. Neerl. 4: 322- 338.

Balsamo A.R \& Thomson W.W.1993. Ultrastructural features associated with secretion in the salt glands of Frankenia grandifolia (Frankeniaceae) and Avicennia germinans (Avicenniaceae). Amer. J. Bot. 80 (11): 1276- 1283.

Batanouny K.H. \& Abo Sitta, Y. M. 1977. Eco- phoysiological studies on halophytes in arid and semi- arid zones- I- Autecology of the salt- excreting halophyte Limoniastrum monopetalum- Acta Bot. Acad. Sci. Hung. 23:13-31.

Bosabalidis A.M. 1992. A morphological approach to the question of salt gland lifetime in leaves of Tamarix aphylla L. Isr. J. Bot. 41: 115- 121.

Campbell C.J. \& Strong J.E. 1964. Salt gland anatomy in Tamarix pentandra (Tamaricaceae). Southwestern Nat. 9: 232- 238.

Campbell N., Thomson W.W. \& Platt K. 1974. The apoplastic pathway of transport to salt glands. J. Exp. Bot. 25: 61-69.

\& Thomon W. W. 1976. The ultrastructural of Frankenia salt glands. Annals of Botany 40: 681- 686.

Carlquist S. 1959. Glandular structure of Holocarpha and their ontogeny. Amer. J. Bot. 46: 300- 308. 
Carpenter J.L., Kerr R. J., Vesk M.L. \& Allaway W.G. 1990. Leaf glands and salt secretion in the mangrove, Avicennia marina. In: Beilby, M.J., Smith, J.R., Walker N.A. (eds.). Membrane transport in plants and Fungi. Australia: Sydeny Univ- Press, 503- 507.

Chapman V.J. 1944. The morphology of Avicennia nitida Jacq. and the function of the pneumatophores. - Bot. J. Linn. Soc. 52: 487- 533.

Das S. 1999. An adaptive feature of some mangrove of Sundarbans, West Bengal. $J$. Pl.Biol.(Korea) 42: 109- 116.

Deng Y., Jiang Y. \& Liu, J. 1998. The xeromophic and saline morphic structure of leaves and assimilating branches in ten Chenopodiaceae species in Xinjiang. Acta Phytoecol . sin. 22, 164: 170- 173.

Drennan P., Berjak P., Lawton J. \& Pammenter N.W. 1985. The functional ultrastructure of the salt glands of Avicennia marina. Proc. Electron Microsc. Soc. S. Afr. 15: 83-84.

Drennan P., Berjak P., Lawton J. \& Pammenter N.W. 1987. Ultrastructure of the salt glands of the mangrove, Avicennia marina (Forsk.) Vierh. as indicated by the use of selective membrane staining. Planta 172: 176- 183.

Drennan P.M., Berjak P. \& Pammenter N.W. 1992. Ion gradient and adenosine triphoshatase localization in the salt glands of Avicennia marina (Forssk.) Vierh. S. Afr. J. bot. 58: 486- 490.

Dschida W.J., Platt- Aloia K.A \& Thomson W.W. 1992. Epidermal peels of Avicennia germinans (L.) Stearn. A useful system to study the function of salt glands. Annals of Botony 70: 501- 509.

Fahn A. \& Shimony C. 1977. Development of the glandular and non- glandular leaf hairs of Avicennia marina (Forssk.) Vierh. Bot. J. Linn. Soc. 74: 37- 46.

Faraday C.D. \& Thomson W.W. 1986a. Structural aspects of the salt glands of the Plumbaginaceae. J.Exp. Bot. 37: 461- 470.

Franke W. 1961. Ectodesmata and foliar absorption. Amer. J.Bot. 48: 683- 691.

Freitag H. \& Breckle S.W. 1992. Importance of bladder hairs for salt tolerance of fieldgrown Atriplex species from a Portuguese salt marsh. Flora 187: 287- 297.

Hagemeyer J. \& Waisel Y. 1988. Excretion of ions $\left(\mathrm{Cd}^{2+}, \mathrm{Li}^{+}, \mathrm{Na}^{+}\right.$, and $\left.\mathrm{cl}^{-}\right)$by Tamarix aphylla. Physiologia Plantarum 73: 541- 546.

Helder R.J. 1956. The loss of substances by cell and tissue (salt glands). In: Ruhland, W. (ed.), Encyclopedia of plat physiology, Vol. II. 468- 480- Springer- Verlag. Berlin.

Hill A.E. \& B.S. Hill. 1973. The Limonium salt gland: a biophysical and structural study. International Review of Cytology 35: 299- 319.

Johansen D.A. 1940. Plant microtechnique, (New York: Nc Graw- Hill). 
Juniper B.E. \& Jeffree C.E. 1983- Plant surface. Edward Arnold (Publishers) Limited.

Karimi S.H. \& Unger I.A. 1989. Development of epidermal salt hairs in Atriplex triangularis Willd.in response to salinity, light intensity, and aeration. Bot. Gaz. 150: 68- 71.

Lambertz P. 1954. Untersuchungen über das Vorkommen von Plasmodesmen in den Epidermisaussenwänden. Planta (Berl.) 44: 147- 190.

Levering C. A. \& Thomson W.W. 1971. The ultrastructure of the salt gland of Spartina foliosa. Planta (Berl.) 97: 183- 196.

Liphschitz N. \& Waisel Y. 1974. Existence of salt glands in various genera of the

Gramineae. New Phytologist 73: 507- 513.

Shomer - Ilan A., Eshel A. \& Waisel Y. 1974. Salt glands on leaves of Rhodes Grass( Chloris gayana Kth.). Annals of Botany 38: 459- 62.

Lüttge U. 1971. Structure and function of plant glands. A. Rev. P. Physiol. 22: 23- 44.

Metcalfe C.R. 1971. Anatomy of the Monocotyledons V. Cyperaceae. Oxford Univ. Press, Ely House, London W.I.

Mooney H., Bjorkman O. \& Trougton J. 1974. Seasonal changes in the leaf characteristics of the desert shrub Atriplex hymenelytra. Carnegie Instn. Yearbk. 73: 846- 852.

Mourad M.M. 1984. Morphological Studies on the Cyperaceae in Egypt. M.Sc. Thesis, Bot. Dept. Fac. Sci. Ain Shams Univ.

Pollak G. 1973. Salt secretion in Aeluropus litoralis (Wild.) Parl. Ph.D. thesis, Tel Aviv Univ.

--------- \& Waisel, Y. 1970. Salt secretion in Aeluropus littoralis (Willd.) Parl. Annals of Botany 34: 879- 888.

Pollak G. \& Waisel, Y. 1971. Salt secretion in halophytes. Teva Veaaretz 12: 234- 238.

Rajput P. \& Sen D.N. 1991. Salt secretion in some exotic species of Atriplex in Semi-arid zone of Rajasthan. Res. Bull. Panjab Univ. Sci. 42: 37- 45.

Reimann C. \& Breckle S.W. 1988. Salt secretion in some Chenopodium species. Flora 180: 289- 296.

Sakai W.S. 1974. Scanning electron microscopy and energy dispersive X- ray analysis of chalk secreting leaf gland of Plumbago Capensis. Amer. J. Bot .61 (1) : 94-99.

Salama F.M., El- Naggar S.M. \& Ramadan T. 1999. Salt glands of some Halophytes in Egypt. Phyton 39: 91- 105.

Schnepf E. 1959. Untersuchungen über Darstellung und Bau der Ektodesmen und ihre Beeinflussbarkeit durch stoffliche Faktoren. Planta (Berl.) 52: 644- 708.

Schumacher W. 1957. Uber Ektodesmen und Plasmodesmen. Ber. Deutch. Bot. Ge. 70: 335- 342. 
Schumacher W. \& Lambertz P. 1956. Uber die Beziehungen zwischen der Stoffaufnahme durch Blattepidermen und der Zahl der Plasmodesmen in den Aussenwänden. Planta (Berl.) 47: 47- 52.

Shimony C. \& Fahn A., 1968. Light and electron microscopical studies on the structure of salt glands of Tamarix aphylla L. J.Linn. Soc. (Bot.) 60: 283- 288.

Sievers A. 1959. Untersuchungen über die Darstellbarrakeit der Ektodesmen und ihre Beeinflussung durch physikalische Faktoren . Flora (Jena) 147, 263- 316.

1960. Über den Einflus von monochromatischem Licht auf die Darslellbarrakeit der Ektodesmen. Zeit. Naturf. 156: 49-52.

Stepanová A.A. 1983. Ultrastructural modification of leaf salt glands in Limonium platyphyllum (Plumbaginaceae) after induction of sodium chloride secretion. Bot. Zh. SSSR 68: 1003- 1012.

Taleisnik L.E. \& Anton M.A. 1988. Salt glands in Pappophorum (Poaceae). Annals of Botany 62: 383-388.

Thomson W.W. \& Liu L.L. 1967. Ultrastructure feature of the salt gland of Tamarix aphyllya (L.) Karst. Planta 73: 201-220.

Vassilyev A. E. \& Stepanová A.A. 1990. The ultrastructure of ion- secreting and nonsecreting salt glands of Limonium platyphyllum. J. Exp. Bot. 41:41-46.

Waisel Y. 1961. Ecological studies on Tamarix aphylla (L.) Karst. III. The salt economy. Pl. Soil. 13: 356- 364.

Waisel Y. 1972. Biology of Halophytes. 141- 165. Academic Pres. New York.

1991. The glands of Tamarix aphylla: a system for salt secretion or for carbon concentration. Physiol. Plant. 83:506-510.

Weiglin C. \& Winter E. 1991. Leaf structures of xerohalophytes from an East Jordanian salt pan. Flora. 185: 405-424.

Zahran M.A.1982. Ecology of the halophytic vegetation of Egypt, in: Sen D.N. \& Rajpurohit K.S.(Eds.), Tasks for vegetation science. 2: pp. 3-20-De Junk, the Hauge.

Ziegler H. \& Lüttge U. 1966. Die Salzdrüsen von Limonium vulgare .I . Die fein struktur . Planta 70 :193 - 206.

1967. Die Salzdrüsen von Limonium vulgare. II. Die Lokalisierung des Chlorids. Ibid .74: 1-17 